\title{
Kekerasan Berbasis Gender dalam Victim-Blaming pada Kasus Pelecehan yang Dipublikasi Media Online
}

\author{
Syarifah Nuzulliah Ihsani \\ Fakultas Psikologi, Universitas Gadjah Mada \\ "Penulis Koresponden: syarifahnuzulliah@mail.ugm.ac.id
}

\section{ABSTRAK}

Kekerasan berbasis gender online sering terjadi di media online. Banyak pemberitaan mengenai pelecehan di internet yang menggiring masyarakat untuk menyalahkan korban. Maraknya victim-blaming terhadap korban pelecehan menyebabkan mereka merasa malu, terancam, dan tidak memperoleh haknya sebagai korban. Bahkan, victim-blaming menyebabkan banyaknya korban pelecehan yang lebih memilih bungkam daripada menceritakan permasalahan mereka karena khawatir akan disalahkan. Penelitian ini bertujuan untuk melihat penyebab victim-blaming pada kasus pelecehan yang dipublikasikan melalui media online agar dapat memberikan rekomendasi kebijakan untuk perlindungan terhadap korban. Penelitian ini dilakukan dengan studi literatur melalui pencarian inklusif literatur yang telah dipublikasi dan mengidentifikasi studi yang berkaitan dengan victim-blaming pada kasus kekerasan berbasis gender yang dipublikasi melalui media online. Hasil penelitian menunjukkan bahwa peran media online terhadap budaya victim-blaming disebabkan karena adanya bias gender pada praktik jurnalistik pada media online. Penggunaan diksi yang bias terhadap korban, menggiring pembaca menerima stereotip yang dikontruksi oleh media online sehingga tindakan victim-blaming sering terjadi.

Kata Kunci: kekerasan berbasis gender; perempuan; victim-blaming, media online

\section{ABSTRACT}

Online gender-based violence often occurs in online media. Many news about harassment on the internet has led people to blame the victim. The victims of harassment often blamed people, which causes them to feel ashamed, threatened, and do not get their rights as victims. Blaming the victim also causes many victims to prefer silence rather than telling the problem for fear of blaming. This study aims to review the causes of victim-blaming of published harassment cases through online media to provide policy recommendations to protect the victims. This research was conducted by studying literature through published literature searches and identifying studies related to victimblaming in published gender-based violence cases through online media. The results demonstrate that gender bias in journalism practices in online media has a role on online media in victim-blaming. The use of victim-biased diction leads the reader to accept stereotypes constructed by online media motivate victim-blaming occurred.

Kata Kunci: gender-based violence; woman; victim-blaming; online media

\section{PENDAHULUAN}

Perkembangan zaman yang diiringi dengan perkembangan teknologi yang semakin pesat serta kemudahan dan luasnya jangkauan akses internet, mejadikan media sosial menjadi populer dikalangan masyarakat. Kondisi masa pandemi COVID-19, memberikan ruang terbatas pada individu untuk melakukan aktivitas di luar rumah karena besarnya risiko terpapar Virus Corona. Sehingga, seluruh kegiatan yang biasanya dapat dilakukan di luar rumah dialihkan menjadi online membuat intensitas penggunaan platform digital meningkat dibandingkan sebelum pandemi. Penggunaan platform digital ini tidak hanya memberikan nilai positif, namun juga memberikan dampak terhadap maraknya kejahatan yang muncul dengan memanfaatkan kemajuan teknologi, salah satunya adalah KBGO atau Kekerasan Berbasis Gender Online (Salamor et al., 2020: 491). 
Sejak 2015, Komnas Perempuan menekankan bahwa pola kasus pada kekerasan gender yang terjadi di ruang online menjadi semakin rumit. Mulai dari memperdaya (online grooming) hingga pelecehan secara online. Berdasarkan Catatan Tahunan Komnas Perempuan tahun 2020, terjadi kenaikan yang sangat pesat pada kasus KBGO. Tahun 2019, kasus KBGO dilaporkan terdapat 241 kasus dan meningkat menjadi 940 kasus di tahun 2020. Hal ini menunjukkan bahwa pada era pandemi COVID-19, kasus KBGO perlu mendapatkan perhatian serius dari seluruh pihak agar dapat tertangani dengan baik dan korban mendapatkan keamanan (Komnas Perempuan, 2021: 2).

Berhubungan dengan KBGO, banyak kasus kekerasan yang dipublikasi dalam berita online. Namun, terkadang berita yang berkaitan didramatisasi dan menggiring masyarakat untuk menyudutkan korban yang sebagian besar merupakan perempuan, khususnya pada kasus pelecehan seksual. Mirisnya, pemberitaan di media massa justru memberikan pembelaan kepada pelaku dengan dalih tidak bisa menahan nafsu seksual (Najib and Sunarto, 2020: 3). Fenomena yang sering terjadi adalah adanya victim-blaming, di mana korban kasus pelecehan seksual yang terekspos di media atau pemberitaan online justru mendapatkan komentar negatif dari pengakses internet. Sehingga, pada kasus pelecehan, baik online maupun yang terjadi di dunia nyata, banyak korban yang merasa malu untuk bersuara atau bahkan sekedar untuk pembelaan diri. Hal ini dikarenakan mereka tidak memperoleh rasa aman jika mereka mengungkapkan apa yang terjadi pada mereka.

KBGO memiliki dampak yang sama seperti kasus kekerasan seksual yang terjadi di dunia nyata, yang mana dampak tersebut dapat dirasakan secara langsung dan bersifat jangka panjang (Prameswari et al., 2021: 56). Adanya komentar-komentar negatif pada pemberitaan terkait kasus pelecehan dapat memberikan dampak buruk pada fisik, emosional, maupun psikologis perempuan yang menjadi korban pelecehan baik pada platform online maupun dunia nyata. Komentar negatif yang menyudutkan korban dapat mempengaruhi kondisi psikologis korban, di antaranya: perasaan tidak berdaya, terisolasi, kecemasan tinggi, hingga depresi, dan trauma. Oleh karena itu, artikel ini bertujuan untuk menggambarkan definisi victim-blaming, melihat dinamika victim-blaming yang dipublikasi media online, pengaruhnya terhadap kesejahteraan, serta rekomendasi kebijakan yang dapat dilakukan untuk melindungi korban dan menangani kasus kekerasan berbasis gender online.

\section{Konstruksi Media Online}

Media massa menjadi salah satu sumber informasi yang dikonsumsi khalayak dan mempengaruhi realitas subjektif bagi pelaku interaksi sosial. Dalam artian, informasi yang tercakup dalam media membentuk gambaran tentang realitas yang nantinya akan mempengaruhi respons dan sikap masyarakat terhadap objek sosial. Sehingga, hal ini menuntut media untuk memberikan informasi yang akurat, terpercaya, dan berkualitas. Media massa sendiri terbagi menjadi beberapa bentuk, di antaranya ada media cetak, elektronik, dan media online. Media online merupakan saluran informasi yang tersedia dengan situs website dan hanya bisa diakses jika terhubungan dengan koneksi internet. Adanya media online ini membuat cakupan informasi menjadi lebih cepat menyebar dan lebih mudah diakses oleh masyarakat kapan dan dimana saja jika terjangkau dengan koneksi internet (Yusman, 2017: 16).

Dalam membentuk konstruksi berita, setiap media memiliki caranya masing-masing untuk membagikan informasi terkait isu-isu atau peristiwa yang terjadi. Ada yang menambahkan, mengurangi, atau menghilangkan bagian yang termuat dalam informasi. Hal ini merupakan framing atau pendekatan atau cara pandang wartawan dalam menyeleksi isu yang akan ditulis. 
Terdapat dua konsep untuk melihat konstruksi realitas yang direfleksikan oleh media. Pertama, media sebagai objek aktif. Dimaksudkan bahwa media berpartisipasi dalam mengkonstruksi pesan, sehingga muncul pandangan bahwa tidak ada realitas yang sesungguhnya dalam media. Kedua, media sebagai objek pasif. Hal ini menjelaskan bahwa media tidak turut berpartisipasi dalam konstruksi pesan, melainkan hanya sebagai penyalur pesan yang sesungguhnya (Yusman, 2017: 18). Sehingga, dalam hal ini, media ditempatkan sebagai sarana yang netral dan memperlihatkan realitas dengan apa adanya. Namun, perlu diingat bahwa media tidak lepas dari bahasa. Sehingga, dalam konstruksi informasi pada media, bahasa menjadi hal yang sangat krusial untuk mempengaruhi respons khalayak.

\section{Kekerasan Berbasis Gender Online}

Kekerasan merupakan tingkah laku yang tidak sesuai dengan undang-undang yang mana menyebabkan kerusakan dan kerugian bagi seseorang baik pada harta beda, psikis, maupun fisik yang berkaitan dengan nyawa sekalipun. Kekerasan dapat didasarkan pada identitas sosial seseorang. Hal ini menjadikan gender sebagai identitas sosial dapat membuat seseorang mengalami kekerasan ketika berkaitan dengan budaya patriarki. Dewasa ini, masih banyak orang yang mungkin bingung membedakan arti dari gender dan jenis kelamin. Gender memiliki konsep yang berdeda dengan jenis kelamin. Jenis kelamin membedakan antara laki-laki dengan perempuan secara biologis yang berkaitan dengan organ reproduksi. Sedangkan, gender merupakan atribusi peran yang terbentuk karena adanya pengaruh konstruksi sosial dan kultural (Prameswari et al., 2021: 57).

Pada budaya patriarki, muncul konsep yang melanggengkan subordinasi bahwa perempuan merupakan lawan dari laki-laki dan menilai bahwa laki-laki lebih dominan daripada perempuan. Konsep ini juga menempatkan perempuan sebagai makhluk lemah yang harus menuruti keinginan laki-laki. Jika tidak mematuhi, maka akan mendapatkan kekerasan. Inilah yang dimaksud dengan kekerasan berbasis gender. Dalam budaya patriarki, dapat terjadi penyangkalan hak-hak perempuan dan ketidaksetaraan dapat terjadi antara kedua jenis kelamin, yaitu laki-laki dan perempuan (Purwanti, 2020: 32). Dengan demikian, dapat didefinisikan bahwa kekerasan berbasis gender merupakan tindakan kekerasan yang mencerminkan proporsi yang tidak sama atau asimetri antara laki-laki dan perempuan (Prameswari et al., 2021: 57). Dengan semakin berkembangnya internet dan media digital, maka juga akan meningkatkan peluang bagi kekerasan berbasis gender untuk dapat terjadi di platform online.

Menurut Komnas Perempuan, jenis kekerasan berbasis gender yang terjadi di media online terbagi menjadi beberapa kategori, di antaranya kegiatan memperdaya (cyber grooming), pelecehan online (cyber harassment), peretasan (hacking), konten ilegal (illegal content), pelanggaran privasi (infringement of privacy), ancaman distribusi foto/video pribadi (malicious distribution), pencemaran nama baik (online defamation), dan rekrutmen online (online recruitment). Internet Government Forum memaparkan, terdapat laporan kasus KGBO dengan jenis yang berbeda. Jenis KGBO ini mencakup spectrum perilaku, seperti halnya penguntitan (stalking), tindakan mengintimidasi, kebencian, dan eksploitasi. Kekerasan berbasis gender online dapat terjadi berkelanjutan hingga masuk ke dunia nyata. Korban atau penyintas dapat mengalami kekerasan yang beragam atau bahkan bisa kombinasi antara penyiksaan fisik, seksual, dan psikologis (Kusuma dan Arum, 2019: 5). 


\section{Pelecehan Seksual}

Kekerasan seksual paling tepat dipahami dengan menggunakan terminologi dari pelecehan seksual. Pelecehan seksual merupakan tindakan berokonotasi seksual yang dilakukan secara sepihak dan tanpa ada keinginan dari korban. Bentuk dari pelecehan seksual dapat berupa tulisan, perkataan secara lisan, isyarat, dan atau perlakuan fisik yang mengarah pada konotasi seksual. Sehingga, semua tindakan berkonotasi seksual yang dilakukan karena adanya pemaksaan dari pelaku tanpa adanya dari keinginan korban yang mengakibatkan penderitaan pada korban, dapat dianggap pelecehan seksual (Winarsunu, 2008). Bukan hanya perempuan, pelecehan seksual juga dapat terjadi pada laki-laki. Pelecehan seks merupakan penyalahgunaan hubungan laki-laki dan perempuan yang mana salah satu pihak merasa dirugikan karena direndahkan martabatnya. Pelecehan seksual pada perempuan dipandang terjadi karena sistem tata nilai yang menempatkan perempuan sebagai second class citizen. Perempuan dipandang lebih lemah daripada laki-laki dan ditempatkan pada posisi subordinasi dan termarginal yang patut untuk dikuasai atau dieksploitasi (Sumera, 2013: 39).

Pelecehan seksual memiliki rentang luas dengan bentuk yang beragam, mulai dari verbal baik berupa komentar maupun gurauan yang tidak baik, perilaku tidak pantas, pemaksaan, hingga ancaman kepada perempuan bila menolak melakukan hubungan seksual. Dikarenakan memiliki rentang yang luas, pelecehan seksual dapat terjadi di manapun seseorang berada. Bahkan, dengan orang yang dikenal, maupun tidak dikenal. Amir dalam Lestari (2019: 200) menyebutkan, bahwa elecehan seksual yang dilakukan oleh orang dikenal, justru akan menimbulkan komentar negatif dari khalayak dengan persentase lebih besar karena dianggap kuat menjadi penyebab terjadinya pelecehan daripada dengan orang yang tidak dikenal. Pelecehan seksual dari orang yang dikenal ini bisa berasal dari pasangan, seperti kekerasan intim pasangan (intimate partner violence). Kekerasan intim pasangan merupakan perilaku agresif yang dilakukan pada pasangan intim. Tindakan ini meliputi kekerasan seksual, fisik kekerasan, penguntitan atau pelecehan, agresi verbal, kontrol paksaan, dan kontrol kesehatan reproduksi atau seksual (Else-Quest and Hyde, 2017: 399). Tidak berbeda dengan pelecehan yang dilakukan oleh orang yang tidak dikenal, pada perilaku kekerasan intim pasangan pun banyak korban yang disalahkan atas tindakan yang dilakukan pasangannya. Budaya menyalahkan korban pelecehan seksual inilah yang disebut dengan victimblaming. Menjamurnya budaya victim-blaming ini disebabkan karena kesadaran masyarakat yang masih minim mengenai pelecehan seksual dan dampaknya pada korban. Sehingga, tidak didapatkan keadilan dan hak untuk para korban pelecehan seksual (Restikawasti, 2019: 19).

\section{Victim-blaming}

Dewasa ini, dilihat dari maraknya laporan kasus kekerasan berbasis gender, perempuan belum dapat memperoleh hak dan kebebasan dalam memberikan suara atau bahkan untuk memberikan pembelaan atas apa yang terjadi kepada mereka. Fenomena yang sering terjadi, umumnya masyarakat akan melabeli korban pelecehan seksual dan menuding korban dengan kesan lebih rendah. Victim-blaming termasuk dalam bagian dari rape culture, di mana hal ini dilakukan dengan menyalahkan dan menganggap bahwa tindakan pelecehan yang terjadi merupakan akibat dari tingkah laku korban. Definisi lain disebutkan bahwa victim-blaming merupakan bagian yang lebih besar dari budaya pemerkosaan dan menganggap kekerasan pada perempuan sebagai sesuatu yang biasa. Dalam hal ini, melalui institusi, perempuan dijadikan target dalam praktik gender, yaitu melalui media dan sistem peradilan pidana (Thacker, 2017: 91). 
Perilaku victim-blaming menyebabkan pelaku pelecehan seksual merasa tidak bersalah dan bebas berkeliaran karena lingkungan sekitar tidak menyudutkan pelaku. Selain bersifat menyalahkan korban sebagai penyebab tejadinya pelecehan seksual, victim-blaming juga membentuk pola pikir dan opini masyarakat untuk ikut melakukan hal yang sama. Hal inilah yang merugikan para korban pelecehan seksual, sehingga mengakibatkan mereka tidak mendapatkan keadilan dan haknya sebagai korban (Restikawasti, 2019: 19).

\section{METODE PENELITIAN}

Artikel kualitatif ini menggunakan pendekatan studi literatur yang bersifat deskriptif. Peneliti mendeskripsikan secara objektif mengenai victim-blaming pada kasus kekerasan berbasis gender di media online. Pengumpulan bahan dilakukan dengan studi kepustakaan dengan melakukan pencarian judul melalui literatur yang telah dipublikasi pada Google Scholar dengan kata kunci: 'kekerasan berbasis gender online', 'victim-blaming', 'pelecehan seksual'. Metode ini dipilih untuk memperoleh landasan teori dari para ahli yang menjadi objek penelitian dan mengidentifikasi studi yang berkaitan mengenai victim-blaming pada kasus kekerasan berbasis gender pada media online.

\section{HASIL DAN PEMBAHASAN}

Konsep victim-blaming dikemukakan pertama kali oleh William Ryan (Lestari, 2019: 199), saat mengkritisi poster iklan dari sebuah perusahaan farmasi. Iklan tersebut dinilai terlalu menyalahkan para ibu atas anak mereka yang meninggal ataupun sakit parah karena memakan krayon. Hal ini dilakukan oleh perusahaan farmasi tersebut untuk mempertahankan kepentingan mereka agar dinilai seolah memihak publik dan berjiwa kemanusiaan. Fenomena inilah yang kemudian menjadi awal dari konsep victim-blaming atau blaming the victim. Ryan menyatakan bahwa victim-blaming menjadi sebuah cara yang digunakan oleh kelompok yang berkuasa untuk mempertahankan kepentingan mereka. Kerangka ideologi victim-blaming ini bersifat membangun setiap tindakan kejahatan, sakit mental, penyimpangan masyarakat, dan pengangguran.

\section{Sikap Masyarakat terhadap Korban Pelecehan Seksual}

Budaya patriarki yang dipegang masyarakat memberikan stigma pada perempuan yang menjadi korban kekerasan seksual. Victim-blaming bermula dari adanya miskonsepsi masyarakat mengenai peran korban dan pelaku pelecehan. Sebuah penelitian menyebutkan bahwa victimblaming merupakan sebuah ideologi yang mendukung rasisme dan ketidakadilan sosial kepada korban pelecehan dengan menemukan kesalahan mereka. Dikarenakan kurangnya edukasi mengenai kebiasaan seksual (sexual behavior) dan kekerasan seksual (sexual violence), masyarakat menjadi cenderung menyalahkan korban pelecehan seksual. Hal ini menjadi faktor mispersepsi dan sikap tidak peduli masyarakat terhadap pelecehan seksual. Masyarakat hidup saling mempengaruhi satu sama lain. Hal ini berpengaruh pada prinsip hidup, perilaku, dan pola pikir seseorang (Restikawasti, 2019: 18). Pelecehan seksual yang sangat marak terjadi di masyarakat dengan victim-blaming yang sering dilakukan, maka akan mempengaruhi orang lain untuk melakukan tindakan victim-blaming juga.

Sejak awal individu dilahirkan, laki-laki dan perempuan disosialisasikan dengan sangat berbeda. Dalam proses sosialisasi ini, peran gender ditetapkan. Peran ini berdampak pada perilaku dan keyakinan individu terhadap diri dan orang lain (Grubb and Turner, 2012: 446). Penggambaran 
perbedaan gender dibentuk oleh masyarakat dan institusi tempat mereka tinggal. Sosialisasi peran gender dari masyarakat mempengaruhi perbedaan perilaku individu, termasuk perilaku seksual. Pada umumnya, laki-laki disosialisasikan sebagai inisiator interaksi seksual. Mereka lebih dominan, agresif, dan menjadi pihak yang memulai tawaran seksual. Sedangkan, perempuan digambarkan dengan sisi yang berlawanan. Perempuan disosialisasikan sebagai pihak yang lebih pasif dan menerima (Bridges, 1991: 292).

Dalam teori sosialisi peran seks, Littleton (2001) dalam Grubb dan Turner, 2012: 446) menyebutkan bahwa pemerkosaan pada pasangan yang berkencan seharusnya dilihat bukan sebagai pemerkosaan, melainkan sebagai bagian dari interaksi seksual yang normal karena hubungan seksual yang dipaksanakan mendukung peran laki-laki sebagai pihak yang dominan. Dengan demikian, sosialisasi peran seks memberikan beberapa bentuk penjelasan mengapa lakilaki agresif secara seksual dan mengapa tindakan pemerkosaan dinormalisasi dalam masyarakat. Burt (1980) dalam Grubb and Turner (2012: 447) menyatakan bahwa perilaku agresif seksual didukung melalui sikap budaya yang mempromosikan keyakinan yang salah tentang pelecehan seksual dan lingkungan yang tidak bersahabat terhadap korban pelecehan. Peran gender tradisional ditetapkan menjadi prediktor signifikan mengenai penerimaan mitos pemerkosaan dan bertanggung jawab atas victim-blaming yang dilakukan individu terhadap korban pelecehan. Oleh karena itu, adanya sosialisasi peran gender tersebut, perilaku masyarakat yang menormalisasi pelecehan seksual membentuk tingkah laku dan pola pikir yang dipengaruhi oleh lingkungan sekitarnya dalam melakukan victim-blaming.

\section{Peran Media Online terhadap maraknya Victim-Blaming}

Kemajuan teknologi saat ini, menyebabkan informasi tersebar luas dengan mudah. Kasus kekerasan dan pelecehan seksual yang disebarkan oleh media menuai komentar negatif dari khalayak. Hal ini dikarenakan media di Indonesia masih mengandung budaya. Dari studi budaya, Ryan William melihat adanya budaya dan komunikasi yang saling berhubungan dan keduanya memiliki dengan masyarakat sebagai tempat produksi, distribusi, dan konsumsi (Sulandjari, 2012). Pada kasus pelecehan seksual, media seringkali lebih dulu menghakimi korban. Tidak hanya pada kasus di dunia nyata yang diberitakan, namun kasus yang dialami seseorang yang diungkapkan pada media sosial juga menggiring khalayak untuk menyalahkan korban (Palulungan et al., 2020: 4). Hal ini membuat teknologi komunikasi dan informasi dapat memberikan kerawanan pada tindakan victim-blaming. Terlebih, saat pandemi COVID-19, seluruh kegiatan yang semula dapat dijalankan di kantor, sekolah, ataupun lokasi di luar rumah, namun, saat pandemi harus dialihkan menjadi via digital dengan jangkauan internet. Sehingga, hal ini membuat paparan informasi dari media online kepada masyarakat meningkat.

Tingginya kasus kekerasan berbasis gender harus mendapat perhatian dari seluruh pihak. Salah satu pihak yang berperan penting adalah media massa. Media baik cetak, elektronik, maupun online memiliki peran sebagai pihak yang menyajikan "realita" untuk dapat dilihat oleh masyarakat. Namun, praktik jurnalistik masih sangat bias gender dan banyak berita yang ditulis dengan judul kontroversial. Berita yang dipublikasikan tidak terbebas distorsi sepenuhnya. Hal ini yang menjadi salah satu kelemahan media. Terdapat maskulinitas yang terkandung dalam teks berita. Maskulinitas ini diperlihatkan sebagai hal yang alamiah agresif dan tidak terkendali. Selain itu, pemilihan diksi dalam berita membuktikan adanya atribusi media. Dalam hal ini, berita menjadi produk yang diproduksi dengan menampilkan konteks atau isi, kekuatan teknis, dan ideologi yang menanggung beberapa konstruksi (Sulandjari, 2012). Media juga mampu 
mendefinisikan realitas yang tidak mampu kita dapatkan. Tentunya, ini akan memicu pembaca untuk menyalahkan korban atas kasus kekerasan yang terjadi (victim-blaming). Konsep victimblaming yang digunakan dalam pemberitaan termasuk dalam kekerasan simbolik yang ditujukan kepada korban kekerasan. Hal ini tentunya menjadi tidak adil jika dipandang dari perspektif gender karena merugikan korban yang mana adalah perempuan. Victim-blaming pada berita muncul karena adanya alienasi gender, di mana tidak menghadirkan korban kekerasan seksual sebagai narasumber berita. Sehingga, berita yang dihasilkan tidak memperoleh keberimbangan. Agar mencapai keberimbangan berita, dapat dilakukan wawancara dengan narasumber lain yang paham akan cara membela korban kekerasan seksual apabila korban tidak berkenan diwawancarai (Lestari, 2019: 205).

Dalam praktik pers, terkadang penulis tidak sadar bahwa bahasa yang digunakan dalam pelaporan merupakan bahasa yang merendahkan perempuan. Victim-blaming disebabkan karena wartawan tidak paham dalam menghasilkan teks berita dan produksi maknanya. Sehingga, teks dalam berita menunjukkan objektifikasi gender dan mengarah pada pornografi (Najib dan Sunarto, 2020: 9). Hal ini juga didukung penelitian dari Indrasty et al. (2018: 100) yang melihat posisi perempuan yang dijadikan objek pemberitaan. Sedangkan institusi pers dan polisi lah yang berperan sebagai subjek. Media menggambarkan perempuan sebagai objek rendah dan termarjinalkan dengan mengumbar kata-kata vulgar dan bermakna buruk. Selain itu, kasus pelecehan terhadap perempuan yang dituliskan, juga dijadikan nilai jual yang mampu menarik pembaca. Posisi korban pelecehan yang dimarjinalkan dalam pemberitaan, merupakan kekerasan yang dilakukan oleh media sebagai subjek atau pihak yang berkuasa atas tulisan dalam berita. Korban kekerasan seksual telah dilecehkan oleh pelaku, ditambah dengan adanya pemberitaan yang menggambarkan dirinya rendah yang merugikan dirinya, membuat korban pelecehan menjadi korban untuk kedua kalinya dan mengalami kekerasan berlipat dalam pemberitaan mengenai dirinya melalui media, yaitu pihak yang berposisi sebagai subjek.

Tidak hanya itu, teks yang dipublikasikan secara online juga sepenuhnya mengikuti kronologi dan keterangan yang hanya diberikan pelaku dan menempatkan pembaca untuk menerima gagasan dan stereotip yang terdapat dalam berita. Berdasarkan teori sikap (standpoint theory), dalam konteks kekerasan seksual, perempuan ditempatkan pada posisi marginal. Hal ini menjelaskan bahwa lakilaki memiliki kedudukan yang lebih dominan, sehingga, konstruksi realita yang dibangun dalam berita juga akan terpengaruh (Littlejohn and Foss, 2016: 480). Oleh karena itu, tidak jarang kita menemukan komentar dari pengguna internet maupun media sosial yang menuliskan komentar negatif yang menyalahkan korban pelecehan.

Banyak komentar negatif yang menghubungkan kasus pelecehan yang diterima korban dengan pakaian yang dikenakan korban. Ketika terdapat pembelaan terhadap korban, justru komentar lain muncul untuk mendukung argumen mereka mengenai korban lah yang menyebabkan pelecehan tersebut terjadi karena penggunaan pakaian yang terbuka bukan merupakan budaya yang diajarkan di negara Indonesia. Padahal, menurut Moor (2010: 124-125) kasus pelecehan tidak ada hubungannya dengan cara perempuan berpakaian dengan keinginan perempuan untuk merangsang pelaku.

Dari beberapa penelitian yang menjelaskan bagaimana victim-blaming terjadi dalam media online, menunjukkan bahwa media memiliki peran dalam kekerasan berbasis gender secara online. Media menjadi gerbang bagi khalayak untuk dapat melihat peristiwa yang terjadi dan cerminan yang menggambarkan fakta. Isi dari media yang merupakan konstruksi dari realitas, memanfaatkan 
bahasa bukan hanya sebagai perangkat yang membangun sebuah berita, tetapi juga dapat menentukan relief mengenai suatu realitas yang berpengaruh pada makna yang dikonstruksikan (Suryadi, 2011: 639). Hal yang ditonjolkan dalam berita akan mudah diingat oleh pembaca. Sehingga, dalam memahami sebuah realitas inilah yang dapat mempengaruhi masyarakat. Sebuah penelitian dari Yusnia (2020: 30) yang menganalisis artikel dari Magdalene.co, melihat bahwa artikel kekerasan yang dimuat dalam Magdalene.co menampilkan kata atau susunan kalimat yang menjelaskan penderitaan perempuan akibat kekerasan dan menganggap laki-laki sebagai penyebab kekerasan. Hal ini membuat pihak perempuan mendapatkan dukungan dan simpati khalayak. Oleh karena itu, peran media dalam membangun realitas yang tidak bias gender sangat diperlukan untuk memberoleh keberimbangan agar tidak terjadi victim-blaming.

Permasalahan victim-blaming yang telah dijabarkan sebelumnya, dapat dijelaskan dengan teori atribusi. Teori atribusi merupakan upaya yang melibatkan kemampuan kognitif individu dalam memahami penyebab di balik orang lain dan diri sendiri berperilaku. Menurut Fiske dan Taylor (2001) dalam Grubb dan Turner 2012: 447), teori atribusi berkaitan dengan bagaimana persepsi sosial menggunakan informasi untuk sampai pada penjelasan kausal suatu peristiwa. Namun, dalam melakukan atribusi, tidak semua mengarah pada kebijaksanaan dalam memutuskan sesuatu. Selain itu, sikap terhadap pelecehan seksual juga berkaitan dengan stereotip peran gender tradisional, khususnya terkait dengan perilaku seksual (Lonsway and Fitzgerald, 1995: 704). Menurut Burt (1980) dalam Grubb dan Turner (2012: 446), analisis sosialisasi peran seks pada pelecehan seksual maupun pemerkosaan menunjukkan bahwa hal tersebut dilihat sebagai perpanjangan dari peran gender tradisional. Teori ini menyebutkan bahwa laki-laki dan perempuan mengembangkan ekspektasi perilaku peran gender selama melakukan interaksi seksual sebagai hasil dari proses perkembangan dan pembentukan sosial. Masyarakat memandang laki-laki sebagai sosok yang kuat, dominan, dan agresif. Sedangkan, perempuan digambarkan sebagai sosok yang lemah, dan rapuh. Perilaku agresif seksual ini didukung melalui sikap budaya yang mempromosikan kepercayaan yang salah tentang pelecehan atau pemerkosaan dan lingkungan yang tidak bersahabat bagi korban pelecehan.

Sikap peran gender yang telah dikaitkan dengan pemahaman yang salah mengenai pelecehan, di mana dukungan stereotip peran gender tradisional biasanya menghasilkan tingkat menyalahkan korban yang lebih tinggi. Hal ini memperjelas bahwa stereotip dan konformitas peran gender memainkan peran dalam pembentukan atribusi kausal tentang skenario pelecehan maupun pemerkosaan. Oleh karena itu, sejauh mana individu memegang keyakinan pada peran gender tradisional menjadi faktor kunci pada victim-blaming. Hal ini mempertegas bahwa stereotip peran gender pada masyarakat memainkan peran dalam skema yang mendorong atribusi kausal dan penetapan kesalahan. Selain itu, victim-blaming juga dipengaruhi oleh mitos pemerkosaan dan kepercayaan pada dunia yang adil. Kedua faktor tersebut, yaitu atribusi dan mitos pemerkosaan saling terkait dan tidak terlepas dari nilai budaya yang dipegang setiap individu. Faktor mitos pemerkosaan ini dapat ditunjukkan melalui peran gender tradisional, yang mana terdapat aturan bagaimana seharusnya individu berperilaku berdasarkan jenis kelaminnya (Wulandari dan Krisnani, 2020: 194). Adanya pergeseran peran tradisional ini, mengakibatkan laki-laki merasa terancam dan timbul sejumlah konsekuensi yang harus diterima perempuan demi menjustifikasi ketidakberdayaan mereka. 


\section{KESIMPULAN}

Budaya victim-blaming yang terjadi di masyarakat memiliki faktor yang beragam. Masyarakat cenderung melakukan victim-blaming dikarenakan kurangnya rasa empati, tidak adanya kesadaran dan edukasi dalam memandang korban pelecehan seksual. Selain itu, kekeliruan dalam atribusi juga menjadi salah satu penyebab individu melakukan victim-blaming. Ditinjau dari penelitian sebelumnya, peran media online terhadap budaya victim-blaming disebabkan karena adanya bias gender pada praktik jurnalistik pada media online. Penggunaan bahasa yang menyudutkan pihak korban menggiring pembaca menerima stereotip yang dikontruksi oleh media online sehingga tindakan victim-blaming sering terjadi. Media sebagai institusi seharusnya lebih sensitif mengenai gender. Diharapkan institusi media atau pers dapat mempertahankan idealisme. Saran yang dapat diberikan dari penelitian ini, karena kita hidup di tengah eratnya budaya patriarki, dapat diterapkan perundangan yang mengatur media agar kegiatan jurnalistik dapat mendukung gerakan feminisme. Selain itu, dapat dilakukan dengan mengembangkan pelatihan perspektif gender kepada jurnalis atau literasi feminisme dalam memuat pemberitaan di media agar dapat memperoleh keberimbangan dan kesetaraan pada kedua pihak dalam pemberitaan.

\section{DAFTAR PUSTAKA}

\section{Buku}

Else-Quest, N. M. dan J. S. Hyde. 2017. The Psychology of Women and Gender: Half the Human Experience + . Sage Publications. Washington, DC.

Komnas Perempuan. 2021. Catatan Tahunan Kekerasan terhadap Perempuan Tahun 2020. Komnas Perempuan. Jakarta.

Kusuma, E. dan N. S. Arum. 2019. Memahami dan Menyikapi Kekerasan Berbasis Gender Online. (Sebuah Panduan SAFEnet). SAFEnet.

Littlejohn, S. W. dan K. A. Foss, K. 2016. Ensiklopedia Teori Komunikasi Jilid 1. Kencana. Jakarta.

Palulungan, L., M. G. H. Kordi, M. T. Ramli, Y. Yunus, I. Fattah. 2020. Mengubah Lewat Berita: Jurnalisme Berperspektif Perempuan, Anak, \& Disabilitas. Yayasan Bursa Pengetahuan Kawasan Timur Indonesia (BaKTI). Makassar.

Purwanti, A. 2020. Kekerasan Berbasis Gender. Bildung. Yogyakarta.

Winarsunu, T. 2008. Psikologi Keselamatan Kerja. UMM Press. Malang.

Jurnal

Bridges, J. S. 1991. Perceptions of date and stranger rape: A difference in sex roleexpectations and rape supportive beliefs. Sex Roles 24(5): 291-307.

Grubb, A. dan E. Turner. 2012. Attribution of blame in rape cases: A review of the impact of rape myth acceptance, gender role conformity and substance use on victim blaming. Aggression and Violent Behavior 17(5): 443-452. doi: doi:10.1016/j.avb.2012.06.002.

Indrasty, R., D. Wibawa, dan Rojudin. 2018. Gender dalam Kasus kekerasan terhadap Perempuan di Media Online. Jurnal Ilmu Jurnalistik 3(1): 90-112. 
Lestari, A. P. 2019. Blaming the Victim: Alienasi Gender dalam Media Online. Jurnal Ilmu Dakwah 39(2): 197-213.

Lonsway, K. A. dan L. F. Fitzgerald. 1995. Attitudinal antecedents of rape myth acceptance: A theoretical and empirical reexamination. Journal of Personality and Social Psychology 68(4): 704-711.

Moor, A. 2010. She Dresses to Attract, He Perceives Seduction: A Gender Gap in Attribution of Intent to Women's Revealing Style of Dress and its Relation to Blaming the Victims of Sexual Violence. Journal of International Women's Studies 11(4): 115-127.

Najib, F. D. dan Sunarto. 2020. Blaming the Victim: Objektifikasi Korban Kekerasan Seksual dalam Pemberitaan di Media Online Balairungpress.Com. Interaksi Online 8(1): 1-11.

Prameswari, J. R. C., D. J. A. Hehanussa, dan Y. B. Salamor. 2021. Kekerasan Berbasis Gender di Media Sosial. PAMALI: Pattimura Magister Law Review 1(1): 55-61.

Restikawasti, A. E. 2019. Alasan Perempuan Melakukan Victim-blaming pada Korban Pelecehan Seksual. Journal of Civics and Moral Studies 4(1): 10-20.

Salamor, A. M., A. N. F. Mahmud, P. Corputty, dan Y. B. Salamor. 2020. Child Grooming sebagai Bentuk Pelecehan Seksual Anak melalui Aplikasi Permainan Daring. SASI 26(4): 490-499.

Sulandjari, R. 2012. Kekerasan Gender dalam Blaming the Victim pada Media. Dinamika Sains 10(23).

Sumera, M. 2013. Perbuatan Kekerasan/Pelecehan Seksual terhadap Perempuan. Lex et Societatis 1(2): 39-49.

Suryadi, I. 2011. Peran Media Massa dalam Membentuk Realitas Sosial. Jurnal ACADEMIA Fisip Untad 3(2): 634-646.

Thacker, L. K. 2017. Rape Culture, Victim-blaming, and the Role of Media in the Criminal Justice System. Kentucky Journal of Undergraduate Scholarship, 1(1): 89-99.

Wulandari, E. P. dan H. Krisnani. 2020. Kecenderungan Menyalahkan Korban (Victim-balming) dalam Kekerasan Seksual terhadap Perempuan sebagai Dampak Kekeliruan Atribusi. Social Work Journal 10(2): 187-197.

Yusman, R. 2017. Kontruksi Media Online tentang Pemberitaan Perizinan Meikarta di www.beritasatu.com dan www.kompas.com Edisi September 2017: 15-30.

Skripsi

Yusnia, B. 2020. Analisis Framing Majalah Daring Magdalene.co Mengenai Kekerasan Perempuan. Skripsi. Universitas Muhammadiyah Surakarta. Surakarta. 